Richard SAKWA, Ph.D. ${ }^{1}$

\title{
THE CLASH OF WORLD ORDERS
}

https://doi.org/10.18485/iipe_balkans_rssc.2020.ch1

\begin{abstract}
The end of the Cold War in 1989 opened the door to the potential transformation of European international politics. In the event, Cold War patterns of behaviour were reproduced in new forms. These include a revived confrontation between the Atlantic powers and Russia, accompanied by the new division of Europe. This geopolitical confrontation is accompanied by renewed ideological divisions, with liberal democratic states apparently ranged against authoritarian systems. However, matters cannot be simply folded into new binaries. Four types of world order contend for hegemony today: the liberal international order; transformative (revolutionary) internationalism; mercantilist nationalism; and conservative (or sovereign) internationalism, each with its own logic and principles. The international system can be considered the hardware, while these four models of world order are viewed as the software. World order is in transition from a previously hegemonic model to a more pluralistic one in which the normative validity of others can be acknowledged. This opens up the potential for a more balanced and dialogical type of international politics. Keywords: International system, world order, Europe, Cold War, sovereign internationalism
\end{abstract}

\section{INTRODUCTION}

The view that international politics today is chaotic and disorderly implies that we have moved away from a more ordered system. ${ }^{2}$ There is little evidence that this is the case. Instead, we are seeing the shift from one dominant model of world order to a more fluid situation in which several models contend. The power and authority of the hegemonic system that took shape after 1945 is declining, while alternative models are becoming more internally coherent and convincing. The Atlantic power system was presaged long before the Second World War, notably in Woodrow Wilson's appeal in 1919 to create what became the League of Nations, accompanied

\footnotetext{
${ }^{1}$ Professor, School of Politics and International Relations, Rutherford College, University of Kent, Canterbury, United Kingdom. E-mail: R.Sakwa@kent.ac.uk.

${ }^{2}$ This paper draws on my paper: Sakwa, 2019.
} 
by a special role for the old imperial powers as they moved to new forms of legitimation based on norms of self-determination and development. This gave rise to the mandate system in the interwar years and full-scale decolonisation after the war. In August 1941 the United Kingdom and the United Stated adopted the Atlantic Charter, which further reinforced the importance of norms in international affairs. In 1949 the Atlantic Charter became the foundation stone of the North Atlantic Treaty Organisation (NATO), which is not only a collective security alliance but also one founded on principles of human rights and democracy. In the 1950s this was complemented by the creation of what became the European Union (EU). This is the Atlantic power system (APS), which until recently was sponsored and guided by the US.

With the collapse of the alternative Soviet model of world order, the APS was rebranded as the liberal international order (LIO). The term had barely been mentioned earlier, but it now effectively claimed to be synonymous with order itself (Ikenberry, 2001, 2011). Instead of returning to some first order questions about the nature of the international system and the most appropriate way to bring the former Soviet bloc and Russia itself into the transformed world order, a singular model of expansion was adopted. The APS had always had expansive ambitions, but these were kept in check as long as the Soviet Union existed. However, when these ambitions were described in terms of the LIO, then its scope was truly universal. This immediately provoked charges of double standards and hypocrisy, since there was ultimately no way to transcend the fact that the LIO was a more ambitious version of the APS and rooted in large part in the same hegemonic structures of power. A particular model of world order now claimed to be universal and applicable to the whole world, in the forms that it had taken in the heartlands of the Atlantic region (Bacevich, 2020).

The Atlantic power system after 1989 reprofiled itself as the liberal international order, and at the same time it became radicalised. At the economic level, globalisation combined free trade with the transformative power of new communications and transport technologies. The LIO really did appear to herald a new world without borders and in which the power of states to manage their own affairs eroded to the point at which some talked of their ultimate redundancy. Third way leaders like Tony Blair in the UK repeatedly argued that large swathes of policy were now beyond the reach of government. In politics, the promotion of democratisation and human rights was embedded in notions of the democratic peace theory. Security for the APS would only be guaranteed if more states became 
democratic; but for that to happen, it was assumed not only that democracies do not go to war with each other, but that they would inevitably align with the Atlantic powers. Kantian ideas about 'perpetual peace' focused on regime type and the values of liberal democratic societies. By shifting the terms of discourse towards the liberal international order, the geopolitical realities and the power hierarchies embedded in the Atlantic system were hidden (Immerwahr, 2019).

The audacious affirmation that a part of the international system could now claim to be the system itself was only viable because of the semantic shift that had taken place. It would be absurd for the Atlantic power system to have global ordering ambitions, yet when couched in terms of an expansive liberal international order, it appeared legitimate. The ideas and processes at the heart of the LIO had become hegemonic after 1945 and effectively unchallenged with the collapse of bipolarity and the disintegration of the Soviet Union. The LIO had undoubtedly delivered enormous public goods in this period, in terms of development and the defence of human rights and dignity. Samuel Moyn describes the human rights globalism that took shape from the 1970s as the 'last utopia' (Moyn, 2012). Little trace remained of a programme of human self-fulfilment and instead the last utopia develops Isaiah Berlin's idea about 'negative freedom' to the limits and asserts what should not be done by humans to each other. The negative space around each individual should not be transgressed. The social solidarity advanced by the welfare states in the advanced capitalist democracies, accompanied by redistributive mechanisms, universal social security and high degrees of equality, was replaced by human solidarity in which state power was tempered by the rights of individuals. This represented an epochal transformation of solidarity that in the end turned the European Union away from 1980 ideas of a 'social Europe' towards one focused on advancing competition by increasingly intrusive regulatory bodies. This is why the LIO delivered repeated economic crises, growing inequality, the erosion of social security rights, and the growing precariousness of the terms and conditions of employment and, ultimately, a new Cold War. Social solidarity of the era of social democracy had given way to human solidarity, but there was not much of the latter either. It was also coming under pressure from alternative models of world order.

\section{THE INTERNATIONAL SYSTEM}

This is why it is important to distinguish particular models of world order from the broader international system. This is something that Henry 
Kissinger failed to do in his masterful book on world order (Kissinger, 2014), and which is the common failing of world order studies. Drawing on English School thinking, the international system can be conceptualised as a three-level construct (Sakwa, 2017, pp. 38-68). At the top, there are the developing apparatus and processes of global governance (termed the secondary institutions of international society by the English School), with the United Nations at its apex and complemented by an increasingly ramified network of international law and normative expectations. The English School distinguishes between primary institutions of international society, comprising sovereignty, territoriality, balance of power, war, international law, diplomacy and nationalism, and describes how these European-generated elements were expanded to the rest of the world (Bull and Watson, 1984). The so-called secondary institutions include not only the United Nations but also other bodies that seek to generalise solidarist practices in a plural international system (Buzan, 2014, pp. 32-36). They include the institutions of international financial governance, derived initially from the Bretton Woods system comprising the World Bank and the International Monetary Fund (IMF), and the system of global economic governance, notably the World Trade Organisation (WTO), Here also are the international legal and environmental covenants, as well as those covering the rules of war and international humanitarian practices. These secondary institutions are by definition universal, whereas the primary institutions generate practices of exclusion, with the Western core imposing its own 'standards of civilisation' and acting as the gatekeeper, notably in the context of colonialism (Gong, 1984).

Many of the secondary institutions are of Western origin, but their development has been governed from the outset less by expansion than by mutual constitution (Dunne and Reus-Smith, 2017). For example, the establishment of the UN drew on various Western traditions as well as Soviet, Chinese, Indian, Islamic and other ideas. As the secondary institutions strengthen and become more genuinely universal, they threaten accustomed patterns of Western hegemony, but at the same time provide the sinews for order after the waning of this hegemony. English School thinking suggests that the international state system evolved out of institutions like the state, territoriality, the balance of power, diplomacy and sovereignty, which formed in Europe and then expanded through colonialism and then revolutionary nationalism across the world to become truly universal, whereas many of the institutions of international society were created by the Allies during the war and reflected Western values, and were at first relatively exclusive. Without challenging this genealogy, it 
should be noted that from the first a universalist dynamic was embedded not only in the primary institutions of international society, but also in the top-level secondary institutions, which have since become generalised as the institutions of 'global governance' and have become more delineated and gained in authority.

This is where we move to the second level. Beneath the solidarity of international governance institutions we have competing states whose relations in English School thinking are governed by the primary institutions of international society. In the original English School formulation, the international society of states devised in Europe expanded in successive waves to encompass the whole world. This really was an 'expansion', enlarging a system into which Russia, with its characteristic ambivalence, was soon incorporated (Neumann, 2011). However, the original expansion model is based on a single level system, but with the development of the 'secondary institutions' and their associated sharing of sovereignty on functional issues (such as the environment), the single-planed model becomes inadequate.

The third level of the international system encompasses a broad range of civil society organisations as well as the media and other forms of societal intervention. This is where economic rationality and the logic of the market operate. Hard-line realists typically dismiss the role that international organisations play in international politics, and even more so sub-state movements and processes. However, in the era of neo-liberalism and globalisation these can have a substantive impact on global processes. The peace movement of the 1980s failed to prevent the deployment of cruise and Pershing missiles to Europe, but fears of re-awakening the mass anti-nuclear movement are part of the calculation of responses to the end of the Intermediate Nuclear Forces (INF) agreement in 2019. Above all, pressure for drastic decarbonisation in the face of the climate catastrophe is now part of the calculus of all rational governments. The upsurge populist movements and sentiments act as a warning to the complacency of entrenched elites. Civil society may well take its revenge on the widening inequalities of the neo-liberal era and reshape our thinking about international order.

\section{Models of global order}

It is in this context that four types of global order have shaped international politics in the post-1945 era. By global orders I mean 'software' systems that provide a consistent set of norms about the correct and most 
appropriate conduct of international affairs. A global order comprises the claim that a particular set of norms and institutions have universal validity. It is not to be confused with globalisation, which is a particular technological, communicative, economic and cultural process that cuts across the various models of world order, although populists and other critics tend to confuse the two. Neither is it to be confused with the globalism that Donald J. Trump contrasted with patriotism in his speech to the United Nations in September 2018 (Ward, 2018). Globalism as we shall see below comes in at least four forms, and some are no less 'patriotic' than the one that he favours. The models are not associated to a specific space but refer to a way of conducting international politics, although they do tend to have a regional focus. The four are ideal types, and the practice of international affairs typically draws from a range of world order repertoires not tied to a single model. States can choose elements from the different models, although the character of a regime and its place in international affairs will predispose it to apply one operating system relatively consistently to the exclusion of others.

\section{The Atlantic power system - liberal international order}

The first is the US-led liberal international order, which was born in the early years of the twentieth century and then formulated by Woodrow Wilson in terms of a commitment to an Atlantic-based system of universal order. The liberal international order is based on an expansive dynamic of universal rules and economic interactions. This has been the most vigorous international order of the modern era, transforming much of the world in its image. The liberal international order combines military, economic and political (normative) sub-orders, each operating according to a specific dynamic but coalescing to create a polymorphic and 'rules-based' international order (Chalmers, 2019).

Contrary to much analysis, this order evolves with the changing character of international politics. Thus the post-war Atlantic power system up to the end of the Cold War in 1989 was shaped by the bipolar confrontation with the Soviet Union and its promotion of an alternative model of world order. The second phase between 1989 and 2014 was characterised by the apparently limitless opportunities opened up by unipolarity. It was in this period that the APS developed a new persona in the guise of the liberal international order. In the absence of a coherent alternative, the LIO became radicalised in at least five ways: the Hegelian, associated with the discourse of the 'end of history'; the Kantian, with the 
extreme emphasis on 'human rights globalism'; the Hobbesian, with numerous ill-judged military interventions intended, among other things, to advance democracy in the world; the Hayekian, which represented the triumph of neo-liberal thinking and the disembedding of market from social relations; and the Marcusean cultural victory of identarian liberalism accompanied by the social fragmentation associated with post-social solidarity politics (Sakwa, 2018). Some of this radicalisation was the natural result of the absence of a viable competitor, allowing the inherent character of the liberal international order to be developed to its full extent; but some of it was hubristic, exposing a dark exclusivity and intolerance of other social orders and traditional life patterns (Pabst, 2018).

In the third phase, the one in which we now find ourselves, the expansive liberal order met its limits both domestically (in the rise of national populism and a revived leftist internationalism) and in international affairs, in the emergence of coherent alternative models of world order. In part this reflects the broader shift of economic power from the West to the East, but also from the larger failure of the expanding US-led liberal international order to find ways to incorporate the periphery without the former outsiders fearing for the loss of their identity. In the Russian case resistance in the end took the form of a New Cold War, while in the case of China long-term civilisational contradictions have re-emerged.

\section{Transformative (revolutionary) internationalism}

The second type of globalism is the one represented until 1991 by the Soviet Union and its allies, which for a time in the 1950s included China. The Soviet Union from the beginning represented an unstable combination of socialist nationalism and revolutionary internationalism, but with the consolidation of Stalin's rule the former predominated. With the disintegration of the Soviet bloc in 1991, the challenge of revolutionary internationalism largely disappeared, although some echoes of the old model remain. At the same time, new sources for the transformational renewal of the international system are emerging, notably the climate emergency. The meaning of revolutionary transformation, of course, in this context has changed from the old Leninist idea of the forcible seizure of power towards the more Gramscian notion of the transformation of social relations, beginning above all in the lower level of our three-story edifice, the arena of civil society, cultural norms and economic interactions. The climate emergency demands new forms of social organisation and a 
thorough rethinking of growth-led models of economic development. Decarbonisation will change not only technological but also social and economic relations. Emerging disruptive digital technologies and biotechnologies are already changing the way that people live and work, and we are only at the beginning of this new revolution. In the end, a new form of transformative (revolutionary) internationalism may be the only answer to the survival of humanity on this planet.

The Non-Aligned Movement (NAM), established in Bandung in 1955, has gained a new vitality to oppose the re-emergence of bloc politics and to give voice to countries overshadowed by the return to great power relations in international affairs. 'Nonalignment 2.0 ' has been advanced as the keystone of India's foreign policy in the new era (Tellis et al., 2012). At the same time, rampant militarism and unchecked arms spending, accompanied by the breakdown in the strategic arms control regime inherited from the Cold War, is provoking the return of active peace movements. The longterm stagnation in middle class and worker incomes accompanied by the erosion of the physical and social infrastructure in the advanced capitalist democracies has prompted a new wave of leftist radicalism. The question of socialism is once again on the agenda (Honneth, 2018). In short, this transformative model of globalism has deep roots in civil society and is forcing change in states and the institutions of global governance. It may well represent a revolution in international affairs as profound as any provoked by world wars and economic crises.

\section{Mercantilist nationalism}

The third type of globalism is gaining increasing traction today. This is the transactional and mercantilist approach adopted by Trump and the various national populist movements of our time (Eatwell and Goodwin, 2018). For Trump the international sphere is simply the extension of the market into the larger domain, where a zero-sum logic predominates and in which there is a ruthless battle for market share. The strong become stronger, while the weak endure what they must. There is no room for multilateral agencies or international alliances, which in Trump's view only constrains the US. Values are humbug, everything is transactional, and there is no need for democracy promotion. This is a stark model of Westphalian internationalism, harking back to an earlier era before 1914 when the first era of globalisation came into contradiction with statist Social-Darwinism. The national interests of sovereign states predominated, and in part the First 
World War represented a revolt against the erosion of state sovereignty by market relations. Today, this logic is reprised in the arguments of radical Brexiteers in the UK, and in the sovereigntist movements in continental Europe, notably in Marine Le Pen's National Rally in France, Thierry Baudet's Forum for Democracy in the Netherlands and Matteo Salvini's (Northern) League (La Liga) in Italy.

The revolt against globalisation took place in the very countries that had taken the lead in outsourcing jobs and services. The benefits of globalisation had been spectacularly badly distributed, and while lifting millions out of poverty in China, destroyed the industrial heartlands of the advanced capitalist democracies while allocating increased wealth to the rich. This is accompanied by a cultural revulsion against not only globalisation but also the apparently heedless cosmopolitanism with which it became associated. This is why the policies advanced by elites in the Anglo-Saxon world are so readily dismissed, and instead the marginalised masses increasingly look for meaning. ${ }^{3}$

The putative defection of the US from the liberal international order that it had done so much to create was at first welcomed by the Russian elite as a vindication of its conservative stance, but it soon became clear that Trump's mercantilist nationalism has no room for allies or even friends, and that it lacks the intellectual or political resources to challenge the US national security establishment. Because of the Russiagate collusion allegations Trump had a fraught relationship with some of the security agencies, but overall the Trumpian insurgency quickly made peace with what Michael Glennon calls the 'Trumanite state' (Glennon, 2015), the vast Cold War military and security apparatus. Russia was once again left out in the cold. However, it was not alone, and America's European allies faced the unprecedented situation in the post-war era of having to give substance to the idea of 'strategic autonomy' (European Union, 2016, pp. 4, 9, 19, 45, 46; Leonard and Shapiro, 2019). Not surprisingly, they talk of chaos in the international system but in fact the crisis is more localised. It reflects the loss of hegemony and strains in the liberal international order, and in particular in the Atlantic power system. A rogue America threatens to spread this chaos globally.

\footnotetext{
${ }^{3}$ This was supplied by the Trumpian slogan of 'Make America great again', and the Brexiteer slogan 'Take back control'; they are meaningless but, paradoxically, offer meaning.
} 


\section{Conservative (sovereign) internationalism}

The fourth type of globalism is the one now associated with Russia, China and their allies in the Shanghai Cooperation Organisation (SCO) and the BRICS (Brazil, Russia, India, China and South Africa). This model of conservative internationalism emphasises sovereign decision-making by nation states, but it also understands the importance of internationalism. As in the two-level European Union, where the Commission and its agencies exercise elements of supranationalism while the member states retain large areas of inter-governmental autonomy in decision-making, so the international system in this sovereign internationalism model operates on the three levels of the international system presented earlier. For conservative internationalists it is the middle floor that is the most important (for Trumpians it is the only one that matters), but this does not preclude a strong normative commitment to the secondary institutions of international society on the top floor, including as we noted earlier the UN and the whole ramified network of international legal, economic, environmental and social governance.

Sovereign internationalists recognise the importance of global governance institutions to manage economic and social processes, and increasingly to deal with the climate crisis and digital innovations, notably cyber-attacks and information management. Their internationalism is more than instrumental, although defenders of this position are certainly not willing to cede extensive supranational powers to international society. We are still a long way from creating a world government, but there remains a constant dynamic (as in the EU) between the two levels. In other words, contrary to the common charge of liberal internationalists that this model represents a regression to non-cooperative Westphalian statism, in fact this model of world order espouses a non-hegemonic and more traditional form of internationalism. It rejects the democratic internationalism promoted by post-Cold War liberal internationalism, based on the expansionist logic of an order that essentially claims to have ready-made solutions to problems of peace, governance and development. Instead, the emphasis is on diplomacy between sovereign subjects, although this does not preclude commitment to the norms embedded in the institutions of global governance.

Russia is presented as the defender of a more conservative and traditional representation of Europe, and thus a strange alignment of Moscow and neo-nativist European national-populists has been forged. Russia thus returned to its nineteenth century manifestation as the defender of conservative cultural values and legitimate government; anti-liberal and 
authoritarian. This representation is at most only partially accurate, but in conditions of New Cold War, Russia was certainly looking for friends wherever it could find them, especially if it could help undermine the unity required for the biannual renewal of EU sanctions. However, neither Russia nor China are genuinely revisionist powers, since both seek to defend the structures of the existing international system, and in the case of China globalisation itself. Their sovereign internationalism is at most neorevisionist, challenging the practices of the US-led liberal international order rather than the principles on which it is based. The hegemonic practices to which they particularly object are generated by the Atlantic power system at the heart of the liberal order, which in their view generates double standards and a false universalism. Partisans of the anti-hegemonic alignment seek to make the global governance institutions in the top tier of the international system genuinely universal.

\section{CONCLUSION}

European history moves in roughly 30-year cycles, and 1989 joins the pantheon as one of those turning points that shape the continent. Like all other great inflexion points, from 1848 to 1919, 1945 and 1968, the significance of the events is debated long after. The absence of a settled meaning and the capacity for endless reinterpretation may well be the characteristic that makes these events so important. This certainly applies to 1989 , the moment when the bipolar security order that took shape in the late 1940s gave way to what was considered to be a moment of European unification. It was also the moment when the long-term challenge of revolutionary socialism as an alternative modernity gave way to what was perceived at the time to be the victory of capitalist democracy, liberalism and the onset of the 'end of history'.

Collectivist models of social emancipation gave way to the primacy of 'negative freedom' and the primacy of individual human rights. Sustained alternatives to capitalist democracy and the international order in which it was embedded were delegitimated. However, the collapse of the Soviet challenge and the victory of the Atlantic power system radicalised what came to be known as the 'liberal international order', which effectively claimed to be synonymous with order itself. This resulted in a two-fold return swing of the pendulum: rethinking forms of national and social solidarity; and the shift towards more pluralist (multipolar) forms of international politics. 
In this context, some points stand out. First, if indeed the liberal international order is a universalised version of the Atlantic power system, then the challenge is to ensure the relative decoupling of the two. The relative decline of the Atlantic power system need not threaten the fundamental postulates of the liberal international order, if the latter can be fully grounded in the autonomous operation of the secondary, as well as the primary, institutions of international society. This would help overcome charges of double standards and the problem of hegemony. This is the implicit challenge advanced by the conservative internationalists. The challenge today may well be to envision a post-Atlantic West. This would allow Europe, and in particular the EU, to advance a genuinely pancontinental post-Atlantic unity.

However, and this is the second point, the sovereign internationalists may well be right to defend the traditional practices of international affairs, above all the accustomed practices of international diplomacy and the niceties of respectful interstate relations, but ultimately they cannot be immune to the normative demands for human solidarity. Some of these states, notably China, have delivered impressive public goods within the framework of social solidarity, but the stick, as in the Soviet bloc before 1989, is pushed too far in one direction. A new balance needs to be found.

Third, while revolutionary internationalism of the traditional sort has waned, the transformative internationalism rooted in the third level of the international system, civil society, is gathering strength. Today the environmental catastrophe is threatening the very sustainability of life on earth. At the same time, the threat of the nuclear holocaust has not disappeared, exacerbated by the onset of a whole suite of new hypersonic and other destabilising weapon systems.

Fourth, the populist return to nationalism, mercantilism and Trumpian 'patriotism' reflects very real problems in post-Cold War domestic and international politics. The sort of globalism (by which national populists primarily mean globalisation, although they also attack the globalism embedded in the UN and other international governance institutions) condemned by Trump has been part of the hollowing out of belief in the efficacy of state intervention and in social solidarity as whole. Populism is the demotic idiom of the oppressed and excluded, but it is also used opportunistically by the privileged and the powerful. Social solidarity is not the alternative to human solidarity but its complement.

Finally, in our European context the challenge is twofold: to find meaningful forms of human solidarity within the European Union, and 
thus once again to turn it into a genuine instrument of peace and emancipation; and to think about the ways that we can meaningfully engage in the biggest challenge of all: devising a post-Atlantic West in which Europe can finally combine societal and human solidarity from one end of the continent to the other.

\section{REFERENCES}

Bacevich, A. (2020). The Age of Illusions: How America Squandered its Cold War Victory. New York, Metropolitan Books.

Bull. H. \& Watson A. (1984). The Expansion of International Society. Oxford, Oxford University Press.

Buzan, B. (2014). An Introduction to the English School of International Relations. Cambridge, Polity.

Chalmers, M. (2019). Which Rules? Why there is no Single 'Rules-Based International System'. Retrieved from https://rusi.org/occasional-papers /Which-Rules-Why-There-Is-No-Single-Rules-Based-InternationalSystem

Dunne, T. \& Reus-Smith, C. (Eds). (2017). The Globalization of International Society. Oxford, Oxford University Press.

Eatwell, R. \& Goodwin, M. (2018). National Populism: The Revolt against Liberal Democracy. London, Pelican.

European Union (2016). Shared Vision: Common Action: A Stronger Europe. A Global Strategy for the European Union's Foreign and Security Policy. European Union, Publications Office of the European Union, Luxembourg.

Glennon, M. J. (2015). National Security and Double Government. Oxford, Oxford University Press.

Gong, G. W. (1984). The Standard of "Civilization" in International Society. Oxford, Clarendon Press.

Honneth, A. (2018). The Idea of Socialism. Cambridge, Polity.

Ikenberry, G. J. (2001). After Victory: Institutions, Strategic Restraint, and the Rebuilding of Order after Major Wars. Princeton, Princeton University Press.

Ikenberry, G. J. (2011). Liberal Leviathan: The Origins, Crisis, and Transformation of the American World Order. Princeton, Princeton University Press.

Immerwahr, D. (2019). How to Hide an Empire: A History of the Greater United States. New York, Farrar, Straus and Giroux. 
Kissinger, H. (2014). World Order: Reflections on the Character of Nations and the Course of History. London, Allen Lane.

Leonard, M. \& J. Shapiro (Eds). (2019). Strategic Sovereignty: How Europe Can Regain the Capacity to Act. Retrieved from https:/ / www.ecfr.eu/page//ecfr_strategic_sovereignty.pdf

Moyn, S. (2012). Last Utopia. Cambridge, Harvard University Press.

Neumann, I. B. (2011). Entry into International Society Reconceptualised: The Case of Russia, Review of International Studies, 37(2), pp. 463-484.

Pabst, A. (2018). Liberal World Order and its Critics: Civilisational States and Cultural Commonwealths. London, Routledge.

Sakwa, R. (2017). Russia against the Rest: The Post-Cold War Crisis of World Order. Cambridge, Cambridge University Press.

Sakwa, R. (2018). 'The International System and the Clash of New World Orders', in Peter W. Schulze (ed.), Multipolarity: The Promise of Disharmony (pp. 27-51). Frankfurt/New York, Campus Verlag.

Sakwa, R. (2019). The International System and Models of Global Order. Russia in Global Affairs, 17(3), pp. 8-31.

Tellis, A. J., Dhume, S., Fontaine, R. \& Scheffer, T. (2012, March 12). Nonalignment 2.0: A Foreign and Strategic Policy for India in the Twenty First Century, retrieved from https:/ / carnegieendowment.org/ 2012/03/12/nonalignment-2.0-foreign-and-strategic-policy-for-indiain-twenty-first-century-event-3587. Accessed 25 December 2019.

Ward, A. (2018, September 25). Read Trump's Speech to the UN General Assembly: "We Reject the Ideology of Globalism and Accept the Doctrine of Patriotism", retrieved from https://www.vox.com/2018/9/ 25/17901082/trump-un-2018-speech-full-text. Accessed 25 December 2019. 